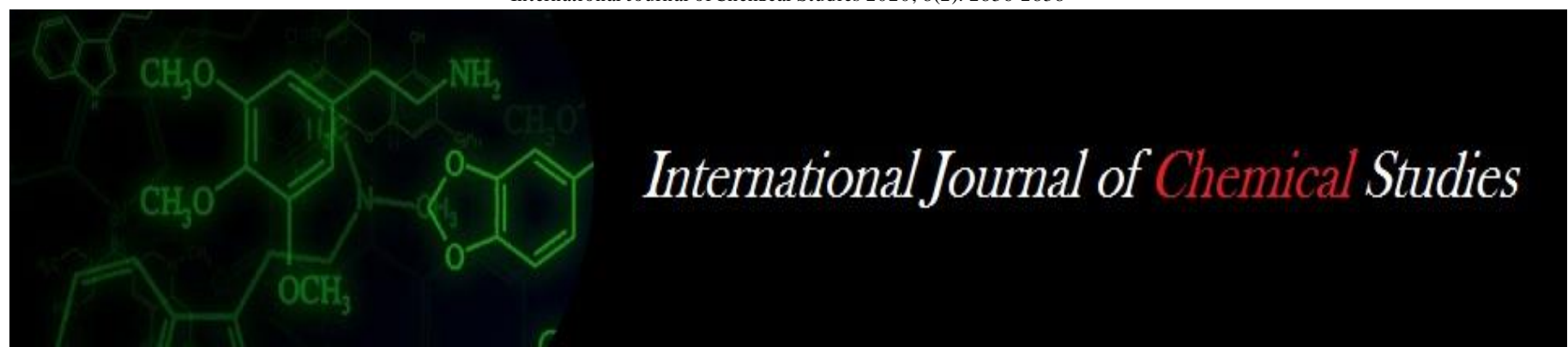

P-ISSN: 2349-8528

E-ISSN: 2321-4902 www.chemijournal.com

IJCS 2020; 8(2): 2836-2838 (C) 2020 IJCS

Received: 15-01-2020

Accepted: 19-02-2020

\section{RK Verma}

Department of Nematology,

Rajasthan College of Agriculture (MPUAT) Udaipur, Rajasthan, India

\section{HK Sharma}

Department of Nematology, Rajasthan College of Agriculture (MPUAT) Udaipur, Rajasthan, India

\section{SS Bhati}

College of Agriculture, Nagaur AU, Jodhpur, Rajasthan, India

\section{Surbhi Garg}

Department of Plant Pathology, Rajasthan College of Agriculture (MPUAT) Udaipur, Rajasthan, India
Corresponding Author: RK Verma

Department of Nematology, Rajasthan College of Agriculture (MPUAT) Udaipur, Rajasthan, India

\section{Investigation on potential of different bio-agents as soil application against root-knot nematode, Meloidogyne incognita infecting tomato}

\author{
RK Verma, HK Sharma, SS Bhati and Surbhi Garg
}

DOI: https://doi.org/10.22271/chemi.2020.v8.i2aq.9179

\section{Abstract}

Anexperiment trial was conducted during 2018-19 for the management of root-knot nematode, Meloidogyne incognita through bio-agents as soil application on tomato in micro plots. Micro-plot was filled with root-knot nematode infested soil $(520 \mathrm{IJ} / 100 \mathrm{cc}$ soil) brought from the pure culture field. Bioagents viz., Purpureocillium lilacinum, Trichoderma harzianum and Pseudomonas fluorescens were added to soil @ 2.5 and 5.0 g per $\mathrm{m}^{2}$. Standard check (Trichoderma viride @ $2.5 \mathrm{~kg} / \mathrm{ha}$ ) and control were also maintained for comparison. Results of bio-agent and dose interaction have indicated that $P$. lilacinum@5.0 g per $\mathrm{m}^{2}$ was found best followed by P. fluorescens @ $5.0 \mathrm{~g} \mathrm{per} \mathrm{m}^{2}$ and T. harzianum @ $5.0 \mathrm{~g}$ per $\mathrm{m}^{2}$. However, T. viride $2.5 \mathrm{~kg} / \mathrm{ha}$ was found superior in respect to plant yield and reducing nematode reproduction on tomato in comparison to all other treatments.

Keywords: Bio-agents, soil application, Meloidogyne incognita, tomato

\section{Introduction}

Tomato [Lycopersicum esculentum (Mill.)] is a most important vegetable crop in the universe. It is cultivated in both temperate and tropical regions of the world and consumed in a various ways like fresh in salad and sandwiches, cooked or processed in ketchup, sauce, juice or dried powder. Tomato plays an important role in human diet which is providing essential nutrients like amino acids, vitamins and minerals etc. It also contains lycopene, which is very important antioxidant and can prevent cancer (Agarwal and Rao, 2000) ${ }^{[2]}$. During 2018-19 India has covered 789 thousand hectare in vegetables and production of 197.59 lakh MT and productivity of 25 ton per ha which contribute about $11 \%$ of their world production (Anonymous, 2017-18a) [3]. The Rajasthan shares 21 thousand ha area of tomato with a production of 85 thousand MT (Anonymous, 2017-18b) ${ }^{[3]}$.

The crop having such economic value is affected by fungi, bacteria, viruses, insects and nematodes. Among various biotic factors plant parasitic nematodes play a major rolefor yield decline in tomato. The crop suffers huge qualitative and quantitative losses due to plant parasitic nematodes like Meloidogyne spp., Rotylenchulus spp., Pratylenchus spp., and Tylenchorhynchus spp. Among these, root-knot nematode, Meloidogyne spp., being obligate sedentary endoparasites with an inherent capacity to interact with other fungal and bacterial pathogens to cause complex diseases, these are the most difficult pests to manage (Fourie and McDonald, 2000) [2]. Internationally a study was conducted on sample estimates from 75 countries which showed that $M$. incognita, M. javanica, M. areneria, M. hapla and other spp., were widespread with 53\%, 50\%, 8\%,8\% and 2\%, respectively (Johnson and Fassuliotis, 1984). In India, about 350 plants are identified as the host of Meloidogyne spp. (Sen and Dasgupta, 1982). It is mostly attacked by M. incognita a pre-dominant as well as widely prevalent species inflicting serious loss in tomato (Sasser, 1990).

\section{Materials and methods}

The experiment was laid in micro-plot filled with infested soil (520 IJs/200 cc soil) carried from the pure culture field. Talc-based formulationof $P$. lilacinum, $T$. harzianum and $P$. fluorescens were added to soil @ 2.5 and $5 \mathrm{~g}$ per $\mathrm{m}^{2}$. Each treatment was replicated three times. 
Standard check (Trichoderma viride @ $2.5 \mathrm{~kg} / \mathrm{ha}$ ) and control were also maintained for comparison. Plants were harvested after 3 month of transplanting.

Observation on the root was wash 'carefully under tap water and stained with 0.1 per cent acid fuschinlac to phenol and after wash set aside in clear lacto phenol for $24 \mathrm{hrs}$. There after the roots were examined scrupulously under a stereoscopic binocular microscope for number of gall per plant, number of females per $5 \mathrm{~g}$ root, number of egg masses per $5 \mathrm{~g}$ root and number of eggs and larvae per egg mass. After removing the plant from the micro-plot, soil was carefully mixed and 200cc soil from each micro-plot were taken and process by Cobb's sieving and decanting technique (Cobb, 1918) [7] followed by Baermann's funnel technique (Christie and Perry, 1951) [6] for estimation of nematode population in soil. The data were subjected to statistical analysis.

\section{Results and Discussion}

Talc-based formulation of bio-agents $P$. lilacinum, $T$. harzianum and $P$. fluorescens were used as soil application @ $2.5 \mathrm{~g}$ and $5 \mathrm{~g}$ per $\mathrm{m}^{2}$ for the managing of root knot nematode, $M$. incognita on tomato. Different bio-agents were found to influence the plant yield and nematode reproduction to a varied degree. However, among these, P. lilacinum, was found most effective, compared to $P$. fluorescens and $T$. harzianumin improving plant yield and suppressing the nematode reproduction(the as well as number of gall per plant, number of females per $5 \mathrm{~g}$ root, number of egg masses per $5 \mathrm{~g}$ root and number of eggs and larvae per egg mass andfinal nematode population/200cc soil).

Among doses, P. lilacinum @ 5g per $\mathrm{m}^{2}$ was found significantly better over other treatments. Results of bio-agent and dose interaction have indicated that P. lilacinum @ 5g per $\mathrm{m}^{2}$ was best over@ $2.5 \mathrm{~g}$ and $5 \mathrm{~g}$ per $\mathrm{m}^{2} P$. fluorescens and $T$. harzianum in improving plant yield and reducing nematode reproduction. However, T. viride $2.5 \mathrm{~kg} / \mathrm{ha}$ was superior in respect to plant yield and reducing nematode reproduction on tomato in comparisons to all other treatment.

Results showed in the table-1 is that application of $P$. lilacinum, T. harzianum and P. fluorescens as soil application @ 2.5 and $5 \mathrm{~g}$ per $\mathrm{m}^{2}$ effectively reduced number of galls per plant, number of females per $5 \mathrm{~g}$ root, number of egg masses per $5 \mathrm{~g}$ root, number of eggs \& larvae per egg masses and final nematodes population $200 \mathrm{cc}$ soil on tomato infected with $M$. incognita. It has been observed in this table that higher dose of bio-agents give superior protection from nematode infection over lower dose. Among following treatments, minimum number of galls perplant (30.88), number of females per $5 \mathrm{~g}$ root (34.43), number of egg masses per $5 \mathrm{~g}$ root (46.56), number of eggs \& larvae per egg mass (16.72) and final nematode population per 200cc soil (19.90) were reduced by $P$. lilacinum followed by $P$. fluorescens at 22.06 , $31.10,41.39,12.54$ and 18.88 per cent and T. harzianum at $19.12,25.57,36.21,10.45$ and 16.33 per cent in nematode population.

These findings are in concurrence with the conclusion of Zaki and Uzma (2009) ${ }^{[17]}$, who reported that use of P. lilacinus against root-knot nematode, $M$. incognita caused higher enlarge in plant growth than P. fluorescens, T. harzianum and $P$. lilacinus also caused higher reduction in galls and nematode multiplication overP. fluorescens, T. harzianum. De Leij and Kerry (1991) ${ }^{[8]}$ report the potential of P. lilacinus as a biological control agent against $M$. arenaria on tomato plants. Significant reduction in the population i.e. more than 80 per cent after the first nematode generation was achieved. Khalil et al. (2012) ${ }^{[12]}$ reported that $P$. lilacinus most valuable treatment on both galls and egg masses triumph 88.23 and $76.94 \%$ decrease, While, less effective treatment $P$. fluorescensgetting $57.53 \%$ galls decrease. Joshi et al. (2012) [11] were weathered fungalbio-agents P. lilacinus@ $2 \mathrm{~g} / \mathrm{kg}$ soil was set up best treatment in greater than ever plant growthand in reduced nematode reproduction over other fungal bio-agents treatments. Hanawi (2014) ${ }^{[10]}$ also reported that $T$. harzianum was the best bio-control agent in increase shoot length and root length $16.2 \%$ and $26.1 \%$, respectively. The $P$. lilacinus was the best bio-agent in reduction of root galls $(57.53 \%)$.

These findings also similar to Baheti et al. (2015) ${ }^{[4]}$, Sen et al. (2016) and Bhati et al. (2019) [5]. Sen et al. (2016) [16] found thatbio-agents viz. Trichoderma viride, Trichoderma harzianum and Pseudomonas fluorescens were used at $2 \mathrm{~g}$ and $3 \mathrm{~g}$ per $\mathrm{kg}$ soil. Soil application with $T$. harzianum at $3 \mathrm{~g}$ per $\mathrm{kg}$ soil was found best treatment followed by $T$. Viride and $P$. fluorescens $3 \mathrm{~g} / \mathrm{kg}$ soil to enhanced plant growth of brinjal and management of $M$. incognita. Bhati et al. (2019) [5] found that Paecilomyces lilacinus at $12 \mathrm{~g} / \mathrm{kg}$ seed was found most effective followed by Pochonia chlamydosporia at 12 $\mathrm{g} / \mathrm{kg}$ seed and Glomus fasiculatum at $12 \mathrm{~g} / \mathrm{kg}$ seed to enhancing plant growth of bitter gourd and to reduce the infection of $M$. incognita.

Table 1: Efficacy of bio-agents against root-knot nematode (M. incognita) at two different doses as soil application on tomato.

\begin{tabular}{|c|c|c|c|c|c|c|c|}
\hline S. No. & Detail of Treatment & $\begin{array}{c}\text { No. of } \\
\text { galls per } \\
\text { plant }\end{array}$ & $\begin{array}{c}\text { No. of } \\
\text { females per } \\
5 \text { g root }\end{array}$ & $\begin{array}{l}\text { No. of egg } \\
\text { masses per } \\
5 \text { g root }\end{array}$ & $\begin{array}{l}\text { No. of eggs } \\
\text { and larvae } \\
\text { per egg mass }\end{array}$ & $\begin{array}{l}\text { Final nematodes } \\
\text { population per } \\
200 \text { cc soil }\end{array}$ & $\begin{array}{c}\text { Yield } \\
\text { (kg/plot) }\end{array}$ \\
\hline $\mathrm{T}_{1}$ & Purpureocillium lilacinum @ $2.5 \mathrm{~g} / \mathrm{m}^{2}$ & $\begin{array}{c}57.00 \\
(16.18)\end{array}$ & $\begin{array}{c}22.67 \\
(24.43)\end{array}$ & $\begin{array}{c}13.67 \\
(29.28)\end{array}$ & $\begin{array}{l}87.67 \\
(8.36)\end{array}$ & $\begin{array}{l}830.00 \\
(15.31)\end{array}$ & 2.50 \\
\hline $\mathrm{T}_{2}$ & Purpureocillium lilacinum @ $5 \mathrm{~g} / \mathrm{m}^{2}$ & $\begin{array}{c}47.00 \\
(30.88)\end{array}$ & $\begin{array}{c}19.67 \\
(34.43)\end{array}$ & $\begin{array}{c}10.33 \\
(46.56)\end{array}$ & $\begin{array}{c}79.67 \\
(16.72)\end{array}$ & $\begin{array}{l}785.00 \\
(19.90)\end{array}$ & 3.35 \\
\hline $\mathrm{T}_{3}$ & Trichodermaharzianum @2.5 g/m² & $\begin{array}{l}62.00 \\
(8.82)\end{array}$ & $\begin{array}{l}28.00 \\
(6.67)\end{array}$ & $\begin{array}{c}16.67 \\
(13.76)\end{array}$ & $\begin{array}{l}90.00 \\
(5.93)\end{array}$ & $\begin{array}{l}850.00 \\
(13.27)\end{array}$ & 2.40 \\
\hline $\mathrm{T}_{4}$ & Trichodermaharzianum @ 5g/m² & $\begin{array}{c}55.00 \\
(19.12) \\
\end{array}$ & $\begin{array}{c}22.33 \\
(25.27) \\
\end{array}$ & $\begin{array}{c}12.33 \\
(36.21) \\
\end{array}$ & $\begin{array}{c}85.67 \\
(10.45) \\
\end{array}$ & $\begin{array}{l}820.00 \\
(16.33) \\
\end{array}$ & 3.15 \\
\hline $\mathrm{T}_{5}$ & Pseudomonasfluorescens @2.5g/m² & $\begin{array}{c}60.00 \\
(11.76)\end{array}$ & $\begin{array}{c}27.00 \\
(10.00)\end{array}$ & $\begin{array}{c}15.67 \\
(18.93)\end{array}$ & $\begin{array}{l}88.67 \\
(7.32)\end{array}$ & $\begin{array}{l}840.00 \\
(14.29)\end{array}$ & 2.45 \\
\hline $\mathrm{T}_{6}$ & Pseudomonas fluorescens @ $5 \mathrm{~g} / \mathrm{m}^{2}$ & $\begin{array}{c}53.00 \\
(22.06)\end{array}$ & $\begin{array}{c}20.67 \\
(31.10) \\
\end{array}$ & $\begin{array}{c}11.33 \\
(41.39) \\
\end{array}$ & $\begin{array}{c}83.67 \\
(12.54) \\
\end{array}$ & $\begin{array}{l}795.00 \\
(18.88) \\
\end{array}$ & 3.25 \\
\hline $\mathrm{T}_{7}$ & Trichodermaviride @ $2.5 \mathrm{~kg} / \mathrm{ha}$ & $\begin{array}{c}40.00 \\
(41.18)\end{array}$ & $\begin{array}{c}17.00 \\
(43.33)\end{array}$ & $\begin{array}{c}9.00 \\
(53.44)\end{array}$ & $\begin{array}{c}76.33 \\
(20.22)\end{array}$ & $\begin{array}{l}760.00 \\
(22.45)\end{array}$ & 3.80 \\
\hline $\mathrm{T}_{8}$ & Control & 71.00 & 34.00 & 19.33 & 98.67 & 980.00 & 1.70 \\
\hline
\end{tabular}




\begin{tabular}{|c|c|c|c|c|c|c|c|}
\hline SEm \pm & & 1.93 & 0.74 & 0.44 & 2.57 & 1.32 \\
\hline CD 5\% & & 5.84 & 2.25 & 1.33 & 7.79 & 24.55 \\
\hline
\end{tabular}

Data are the average of three replications, Initial Nematode Population 520 larvae/ 200 cc Soil, Values in parentheses are (\%) increase or decrease over control, Plot size $=2 \mathrm{~m}^{2}$

\section{Acknowledgement}

The authors are highly thankful to The Dean, Rajasthan College of Agriculture and The Director Research, MPUAT, Udaipur (Raj.) to provide necessary facilities and technical guidance during the course of investigation.

\section{References}

1. Aalders LT, Minchin R, Hill RA, Braithwaite M, Bell NL Stewart A. Development of a Tomato Root Knot Nematode Bioassay to Screen Beneficial Microbes. New Zealand Plant Protection. 2009; 62:28-33.

2. Agarwal S, Rao A. Tomato lycopene and its role in human health and chronic diseases. Canadian Medical Association of Journal. 2000; 163:739-44.

3. Anonymous. Ministry of agriculture cooperation and farmer welfare, Government of India, New Delhi, 201819.

4. Baheti BL, Dodwadiya Mukesh, Rathore BS, Bhati SS. Bio-agents: an effective and ecofriendly option for the management of maize cyst nematode, Heterodera zeae on sweet corn (Zea mays L. saccharata). Journal of Biopesticides. 2015; 8(2):141-146.

5. Bhati SS, Baheti BL, Kumhar RN. Bio-agents: An Effective Method for Suppression of Root-knot Nematode, Meloidogyne incognita infecting Bitter Gourd (Momordica charantia L.) as Seed treatment. Journal of Entomology and Zoology Studies, 2019; 7(5):1197-1201.

6. Christie JR, Perry VG. Removing nematode from soil. Proceedings of Heminthological Society of Washington, 1951; 18:106-108.

7. Cobb NA. Estimating the nematode population of soil. U.S. Dept. Agr. Bur. Plant Ind. Agr. Tech. Cir. 1918; 1:148.

8. De Leij FA, Kerry BR. The nematophagous fungus Verticilium chlamydosporium as a potential biological control agent for Meloidogyne arenaria. Rvue Nematol. 1991; 14:157-164.

9. Fourie, MC Donald. Nematodes. ARCLNR Leaflet. Crop Protection. Sergodha, 2000.

10. Hanawi MJ. A comparative study between some biocontrol agents and the nematicide furfural on growth of tomato plants and pathogenesis of $M$. javanica under green-house condition. Wasit Journal for Science \& Medicine, 2014; 7:107-115.

11. Joshi G, Bhargava S, Sharma MK. Management of Rootknot Nematode, Meloidogyne incognita (Kofoid \& White) Infecting Tomato by using Fungal Bio-agents. Indian Journal of Nematology. 2012; 42:129-131.

12. Khalil MSE, Allam AFG, Barakat AST. Nematicidal activity of some biopesticide agents and microorganisms against root-knot nematode on tomato plants under greenhouse conditions. Journal of Plant Protection Research, 2012; 52:1.

13. Khan AS. Screening of tomato cultivars against root knot nematodes and their biological management. Thesis Research Paper. University of Agriculture. Faisalabad, Pakistan. 2009.

14. Reddy DDR. Analysis of crop losses in tomato due to Meloidogyne incognita Indian Journal of Nematology. 1985; 15:55-59.
15. Sasser JN. Root- knot nematode. A global menace to crop production. Plant Disease, 1980; 64:36-41.

16. Sen K, Sharma HK, Bhati SS, Nama CP, Pushpa. Effect of bio-agents as soil application against root-knot nematode, Meloidogyne incognita infecting brinjal. International Journal of Agriculture Sciences, 2016; 8(33):1687-1689.

17. Zaki A, Siddiui, Uzma S. Effects of antagonistic fungi, wastes materials and urea on the population of Meloidogyne incognita and growth of tomato. Acta Phytopathologicaet Entomologica Hungarica, 2009; 44(2):373-381. 